38 González-Blanch C, Alvarez-Jiménez M, Rodríguez-Sánchez JM, Pérez-Iglesias R, Vázquez-Barquero JL, Crespo-Facorro B. Cognitive functioning in the early course of first-episode schizophrenia spectrum disorders: timing and patterns. Eur Arch Psychiatry Clin Neurosci 2006; 256 364-71.

39 Peralta V, Cuesta MJ. A dimensional and categorical architecture for the classification of psychotic disorders. World Psychiatry 2007; 6: 36-7.

40 Reichenberg A, Weiser M, Rapp MA, Rabinowitz J, Caspi A, Schmeidler J, et al Pre-morbid intra-individual variability in intellectual performance and risk for schizophrenia: a population-based study. Schizophr Res 2006; 85: 49-57.

41 Cannon M, Caspi A, Moffit TE, Harrington H, Taylor A, Murray RM, et al. Evidence for early-childhood, pan-developmental impairment specific to schizophreniform disorder: results from a longitudinal birth cohort. Arch Gen Psychiatry 2002; 59: 449-56.

42 Heaton RK, Temkin N, Dikmen S, Avitable N, Taylor MJ, Marcotte TD, et al. Detecting change: a comparison of three neuropsychological methods, using normal and clinical samples. Arch Clin Neuropsychol 2001; 16: 75-91.
43 Keefe RS, Sweeney JA, Gu H, Hamer RM, Perkins DO, McEvoy JP, et al. Effects of olanzapine, quetiapine, and risperidone on neurocognitive function in early psychosis: a randomized, double-blind 52-week comparison. Am J Psychiatry 2007; 164: 1061-71.

44 Cuesta MJ, Peralta V, Zarzuela A. Effects of olanzapine and other antipsychotics on cognitive function in chronic schizophrenia: a longitudinal study. Schizophr Res 2001; 48: 17-28.

45 Lezak MD. Neuropsychological Assessment (3rd edn). Oxford University Press, 1995.

46 Vickers AJ. How many repeated measures in repeated measures designs? Statistical issues for comparative trials. BMC Med Res Methodol 2003; 3: 22

47 Allison DB, Allison RL, Faith MS, Paultre F, Pi-Sunyer FX. Power and money: designing statistically powerful studies while minimizing financial costs. Psychol Methods 1997; 2: 20-33.

\section{Psychiatrists in 19th-century fiction}

\title{
Armadale (1866), Wilkie Collins
}

\section{Fiona Subotsky}

Lunatic asylums appear in other novels of Wilkie Collins, notably The Woman in White and Jezebel's Daughter, but their medical attendants are not significant for the stories. The villainous Dr Le Doux of Armadale makes up for this. He is represented as not only foreign (suspicious in itself) but unqualified; he has previously practised under another name as an abortionist. Collins can thus distance himself from medical criticism.

Wilkie Collins (1824-1889) largely wrote 'sensation' novels, with a strong element of suspense, rather than the clearly supernatural; however, 'gothic' motifs are readily recognisable. For instance, the approach to Dr Le Doux's Sanatorium in Hampstead is described thus:

'The day was overcast, and the place looked very dreary ... at one corner of this scene of desolation stood a great overgrown dismal house, plastered with drab-coloured stucco, and surrounded by a naked, unfinished garden, without a shrub or flower in it - frightful to behold... The pallid withered old manservant in black, who answered the door, looked as if he had stepped up out of his grave to perform that service . . . I shivered as I crossed the threshold.'

Dr Le Doux has set up his new asylum as a money-making venture and has sent an invitation for a tour to the local population. Inside, by way of advertisement, he has a 'collection of photographic portraits of men and women' illustrating separately 'the effects of nervous suffering' and 'the ravages of insanity... while the space between was occupied by an elegantly illuminated scroll, bearing inscribed on it the timehonoured motto, "Prevention is better than Cure." ' He also has exhibits serving to underline his (false) scientific credentials and to repel and fascinate the visitors and the readers:

'Horrible objects in brass and leather and glass, twisted and turned as if they were sentient things writhing in agonies of pain ... shapeless dead creatures of a dull white colour floated in yellow liquid'.

The doctor is also a master of technology, with the very latest in provision and gadgetry for the comfort and treatment of his patients, notably the ventilation method, which he is later persuaded to put to deadly use:

'The asthmatic nervous patient gasps with terror at the idea of a chemical explosion in his room. I noiselessly fumigate one of them; I noiselessly oxygenize the other, by means of a simple apparatus fixed outside in the corner here. It is protected by this wooden casing; it is locked with my own key; and it communicates by means of a tube with the interior of the room. Look at it!'

In league with the evil Miss Gwilt, Dr Le Doux's plan is to trick the hero Armadale into staying, and then kill him. Subsequently, he intends to declare Armadale to have been deluded and 'certify his brain to have been affected by one of those mysterious disorders, eminently curable, eminently fatal'. The doctor is extremely well informed about the regulations of his day. 'This is not a mad-house; this is not a licensed establishment; no doctors' certificates are necessary here!' Later, however, he anxiously reflects that:

'A note may be smuggled out of the house, and may reach the Commissioners in Lunacy. Even in the case of an unlicensed establishment like mine, those gentlemen - no! those chartered despots in a land of liberty - have only to apply to the Lord Chancellor for an order, and to enter (by heavens, to enter My Sanatorium!) and search the house from top to bottom at a moment's notice!'

Suffice it to say that the plan does not work out as expected, and Miss Gwilt is found dead, possibly from an apoplexy. The epilogue comprises a letter from the family solicitor, who suspects Dr Le Doux of a great deal, but nothing can be proved. Indeed, his friends and admirers are about to present him with a Testimonial expressing sympathy. The solicitor concludes ruefully that: 'In this enlightened nineteenth century, I look upon the doctor as one of our rising men'. 